\title{
ЕЛЕКТРОННИЙ СУД ЯК АДМІНІСТРАТИВНО-ПРАВОВА КАТЕГОРІЯ
}

Обрусна С. Ю., Пасинчук К. М.

\begin{abstract}
Mета статmі - на підставі аналізу чинного вітчизняного законодавства, міжнародних нормативно-правових актів, думок окремих правників визначити зміст і сутність електронного суду як адміністративно-правової категорії.

Авторами зазначено, що для успішного впровадження проєкту «Електронний суд» важливе значення має не лише прийняття відповідних нормативно-правових актів та проведення організаційних заходів, а й розроблення наукової концепції в межах науки адміністративного права. Нині не сформовані певні доктринальні підходи, належний понятійно-категоріальний апарат, який би став науковим підгрунтям подальшої розробки і впровадження електронного суду. Це стосується і самого поняття «електронний суд».
\end{abstract}

Зміст категорії «електронний суд» поки що не отримав правового визначення у вітчизняному законодавстві, хоча сама вона законодавчо оформлена. Висловлено думку, що вітчизняне правове поле потребує формулювання поняття «електронний суд» та закріплення його на законодавчому рівні в межах Закону України «Про судоустрій та статус суддів». Наголошено на важливості розроблення та прийняття окремого закону щодо організації дистанційного електронного правосуддя.

Зазначено, що подальше впровадження електронного суду в Україні передбачає системні діі щодо удосконалення законодавства, технічно-інформаційного забезпечення судів, розроблення заходів і систем забезпечення захисту інформації, правового регулювання питань відповідальності осіб за порушення в цій сфері, вжиття заходів попередження кіберзлочинності, проведення навчальних семінарів серед працівників апарату суду та інших користувачів системи, широку просвітницьку роботу серед населення, систематичний моніторинг ефективності роботи системи та їі постійну модернізацію тощо. Все вищевказане дає змогу говорити про електронний суд як адміністративно-правову категорію.

У результаті проведеного аналізу автором запропоновано розуміти, що електронний суд як адміністративно-правова категорія $\epsilon$ складником електронного врядування, порівняно самостійною та унікальною формою судового адміністрування та юридичного процесу, заснованою на інформаційних технологіях, що забезпечують повний цикл руху документації та розгляду судової справи в електронному форматі, який має легальну юридичну природу.

Ключові слова: судова влада, судова система, суд, правосуддя, електронне правосуддя.

Obrusna S. Yu., Pasinchuk K. M. Electronic court as a legal and administrative category

The purpose of the article is to define the content and determine the essence of e-court as a legal and administrative category based on the analysis of the current domestic legislation, international normative legal acts and lawyers' opinions.

It is noted that for the successful implementation of Electronic court project it is important not only to adopt relevant regulations and organizational measures, but also to develop a scientific concept within the science of administrative law. The content of the category has not got a legal definition in domestic law yet, although it has been legally formalized. The authors express the opinion that domestic legislation requires the concept formulation and consolidation at the legislative level - within the Law of Ukraine on the Judiciary and the Status of Judges. The importance of developing and adopting a separate law on distance e-justice is emphasized.

It is highlighted that further introduction of e-court in Ukraine involves systematic actions. They are technical and information support of courts; development of measures and systems to ensure information security; legal regulation of responsibility in case of violations; measures to prevent cybercrime; court staff trainings; educational campaign among population, monitoring of the system effectiveness and its constant modernization, etc. All the above allows considering e-court as an administrative and legal category.

As a result of the analysis, the authors suggest forming the awareness that e-court, as a legal and administrative category, is a component of e-government, a relatively independent and unique form of judicial administration and legal process based on information technology that provides a full cycle of documentation flow and litigation in an electronic format and has genuinely legal nature.

Key words: judiciary, judicial system, court, justice, e-court, e-justice.

(c) Обрусна С. Ю., Пасинчук К. М., 2020 
Постановка проблеми та іï актуальність. Стрімкий розвиток сучасних інформаційних технологій вплинув на всі сфери людської діяльності та став незмінним засобом ефективного управління, в тому числі й у сфері організації роботи суду та здійснення правосуддя. Електронний суд - порівняно нове явище в Україні, що розвивається як частина загальновизнаної в сучасному інформаційному суспільстві моделі електронного врядування, покликаної надавати швидкі і якісні державні послуги населенню. Разом із тим без належного наукового обґрунтування практичне впровадження як електронного уряду, так і електронного суду може бути малоефективним.

Аналіз останніх досліджень i публікацій. Проблемам електронного судочинства у вітчизняній юридичній науці здебільшого приділено увагу на рівні наукових публікацій. Питання запровадження електронного суду останнім часом досить часто висвітлюються в засобах масової інформації, соціальних мережах, вебсайтах судів тощо. Але більшість публікацій мають науково-популярний, прикладний, публіцистичний характер, що можна пояснити новизною самого проєкту.

Перший досвід і перспективи подальшого впровадження електронного суду узагальнено в монографії О. Бринцева [1]. В. Куценком проаналізовано поняття «адміністративно-правове забезпечення електронного суду» та визначено його зміст [2]. Окремі питання електронного судочинства в ракурсі дослідження адміністративно-правового аспекту надання судових послуг розглянуто в дисертаційній роботі О. Іваненка [3]. Аналізуючи проблеми та сучасні тенденції судового реформування, досліджує електронний суд і Р. Крусян [4]. Низку публікацій присвячено дослідженню організаційно-правових засад впровадження Єдиної судової інформаційно-телекомунікаційної системи, що має забезпечити ефективне електронне правосуддя [5]. 3'являються дослідження, в яких аналізуються окремі процесуальні аспекти електронного судочинства [6].

Разом із тим $\epsilon$ незначна кількість монографій та дисертаційних робіт, присвячених вищевказаній проблематиці. Тому проблеми впровадження електронного суду з погляду загального адміністративного права варто звести до таких: по-перше, недостатнє теоретико-правове підґрунтя вказаного проєкту, по-друге, поки що не сформовано належний понятійно-категоріальний апарат, який би став науковою основою розробки і впровадження електронного суду. Це стосується і самого поняття «електронний суд».

Метою статті $\epsilon$ визначення змісту і сутності електронного суду як адміністративно-правової категорії. Для досягнення вказаної мети варто проаналізувати погляди окремих правників на вказану проблему, чинне вітчизняне законодавство, міжнародні нормативно-правові акти, вітчизняну практику впровадження електронного суду.

Виклад основного матеріалу. На позначення відносин, що виникають у сфері функціонування судової гілки влади, та реалізуються із залученням сучасних інформаційно-телекомунікаційних систем та програмного забезпечення як загалом, так і щодо вчинення окремих процесуальних дій, вживаються такі терміни, як «електронний суд", «електронне судочинство», «електронне правосуддя (юстиція)», «цифровий суд», «віртуальний суд», «кіберсуд» тощо, що можна пояснити розрізненістю підходів до розуміння стратегічної мети впровадження в судову діяльність інформаційних технологій, відсутністю належної наукової концепції електронного суду, в тому числі сформованого понятійно-категоріального апарату, нормативного закріплення його змісту тощо.

Як свідчить аналіз наукових публікацій, «електронний суд», «електронне правосуддя», «електронне судочинство» розглядають як однорядові терміни або ж розмежовують ї. Також автори більшості публікацій не визначають зміст самого поняття «електронний суд», а називають та характеризують його структурні елементи. Крім того, відсутні єдині підходи щодо визначення змісту вищевказаного поняття.

Так, А. Коршун зазначає, що про електронне правосуддя варто говорити не лише як про частину поняття «правосуддя», а як і про один із способів його реалізації [7, с. 23]. Саме з таких позицій «електронний суд» може розглядатися як категорія адміністративного права.

Н. Телешина електронне правосуддя визначає як спосіб здійснення правосуддя, що базується на використанні інформаційних технологій [8, с. 49], тобто акцентує на судовому процесі, а отже, розумінні електронного правосуддя у вузькому значенні.

Погоджуємося 3 думкою А. Коршуна, що варто розмежовувати поняття «електронний суд» i «інформатизація судів» [7, с. 23]. Останнє означає, що суди використовують у своїй діяльності комп'ютерну техніку як підручний засіб, а не процесуальний інструмент. Інформаційні нововведення, що стосуються способів спілкування осіб, учасників процесу, розміщення судових актів у мережі Інтернет, забезпечення інформацією про рух справ тощо, також не варто вважати чітким визначенням електронного правосуддя.

Як наголошують Н. Федосєєва та М. Чайковська, об'єднання судів в єдину комп'ютерну мережу, 


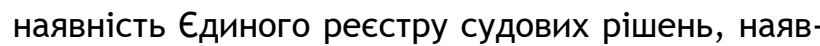
ність вебсайтів судів - це теж не електронне правосуддя [9, с. 2]. Вважаємо, що з такими підходами варто погодитись. Водночас вказані автори називають важливі елементи електронного правосуддя в розумінні його широкого значення.

Тому слушною $\epsilon$ думка С. Романенкової, яка вважає, що поняття «електронне правосуддя» варто розглядати в широкому та вузькому значеннях. У вузькому значенні електронний суд - це змога суду та інших учасників судового процесу здійснювати передбачені нормативно-правовими актами дії, що безпосередньо впливають на початок та хід судового процесу [10, с. 31].

Схоже тлумачення електронного суду пропонує і А. Коршун, зазначаючи, що це сукупність різних автоматизованих інформаційних систем (сервісів), які дають змогу суду та іншим учасникам судового процесу здійснювати передбачувані нормативно-правовими актами дії, що опосередковуються електронною формою вираження процесуальної інформації та взаємодії учасників судочинства $[7$, с. 50$]$.

У широкому значенні електронний суд - нормативно-правове забезпечення, організація роботи сукупності різних автоматизованих інформаційних систем - сервісів, що забезпечують доступ до правосуддя та його здійснення [10]. Саме розуміння поняття «електронний суд» у широкому значенні варто розглядати як адміністративно-правову категорію.

В. Куценко, аналізуючи проблеми адміністративно-правового забезпечення електронного суду, тлумачить поняття «електронний суд» саме з погляду адміністративного права: це складник інформаційного суспільства, порівняно самостійна унікальна форма адміністративної судової діяльності та юридичного процесу, заснованого на інформаційних технологіях з елементами штучного інтелекту, що забезпечують повний цикл руху документації та розгляду судової справи в електронному форматі, що має легальну юридичну природу [9]. Загалом підтримуючи автора, вважаємо, що таке формулювання потребує певних уточнень.

На основі аналізу поглядів науковців на визначення поняття «електронний суд» можна сформулювати його визначення з погляду науки адміністративного права: електронний суд - складник електронного врядування, порівняно самостійна та унікальна форма судового адміністрування й юридичного процесу, заснованого на інформаційних технологіях, що забезпечують повний цикл руху документації та розгляду судової справи в електронному форматі, що має легальну юридичну природу.
Зміст категорії «електронний суд» поки що не отримав правового визначення у вітчизняному законодавстві, хоча сама вона законодавчо оформлена, на що вказано у п. 9 ст. 152 Закону України «Про судоустрій і статус суддів» [11]. Окремі дослідники висловлюють думку, що ії зміст розкрито через категорію «Єдина судова інформаційно-телекомунікаційна система» у ст. $15^{1}$ вказаного закону, з чим не можна погодитись повною мірою, оскільки у вказаній статті визначено структурні елементи вказаної категорії, але не ії зміст.

Міжнародні правові джерела визначають зміст поняття «електронний суд» та його структурні елементи. Так, Рекомендація CM/Rec (2009) 1 KM Р€ державам-членам від 18 лютого 2009 р. містить дефініцію електронного правосуддя та визначає його як використання інформаційних та комунікаційних технологій у реалізації правосуддя усіма зацікавленими сторонами в юридичній сфері з метою підвищення ефективності та якості державних служб, зокрема для приватних осіб та підприємств, що включає в себе електронний зв'язок і обмін даними, а також доступ до судової інформації [12].

У Рекомендації Rec (2001) 3 KM P€ визначено елементи електронного правосуддя: відкриття провадження за допомогою електронних засобів; здійснення подальших процесуальних дій у рамках провадження в середовищі електронного документообігу; одержання відомостей про хід справи шляхом одержання доступу до судової інформаційної системи; одержання інформації про результати провадження в електронній формі тощо [13].

Як бачимо, вітчизняне правове поле потребує формулювання поняття «електронний суд» та закріплення його на законодавчому рівні в межах Закону України «Про судоустрій та статус суддів».

Ідея інформатизації всіх сфер суспільного життя, в тому числі і судочинства, в Україні була закладена Законом України «Про основні засади розвитку інформаційного суспільства в Україні на 2007-2015 роки» [14], а одна із перших концепцій «Електронного суду» в Україні розроблена в 2012 році Державним підприємством «Інформаційні судові системи» на розвиток положень низки законів, Концепції галузевої програми інформатизації судів загальної юрисдикції, інших органів та установ судової системи і Стратегічного плану розвитку судової влади в Україні на 2013-2015 роки.

Реалізацію пілотного проєкту щодо обміну електронними документами між судом та учасниками судового процесу було розпочато у Святошинському районному суді міста Києва та апеляцій- 
ному суді Дніпропетровської області з 15 жовтня 2012 р. 32015 р. пілотний проєкт «Електронний суд» запрацював у трьох судах Одеської області [1]. У липні 2016 р. організаторами проєкту презентовано його позитивні результати та наголошено на неможливості повного завантаження такої практики в судову систему внаслідок недосконалості чинного законодавства, чим і були зумовлені подальші зміни нормативного поля, зокрема, прийняття Закону України «Про внесення змін до Господарського процесуального кодексу України, Цивільного процесуального кодексу України, Кодексу адміністративного судочинства України та інших законодавчих актів». Відповідно до ст. $15^{1}$ і п. 8 ч. 1 ст. 152 Закону України «Про судоустрій і статус суддів» було розроблено та затверджено Концепцію побудови Єдиної судової інформаційної-телекомунікаційної системи.

34 червня 2018 р. у 18 пілотних судах України розпочалося тестування підсистеми Єдиної судової інформаційно-телекомунікаційної системи (ЄСІTC) «Електронний суд», а з 22 грудня 2018 р. у всіх місцевих та апеляційних судах розпочалась експлуатація підсистеми «Електронний суд» у тестовому режимі [15].

Єдина судова інформаційно-телекомунікаційна система мала запрацювати з 1 березня 2019 р., але Державна судова адміністрація України відтермінувала запуск ЄСІТС відповідно до рішення Вищої ради правосуддя та враховуючи результати обговорення питання з судами, іншими органами та установами системи правосуддя [16]. 07.11.2019 р. ДСА затверджено Концепцію в новій редакції, якою змінено підходи до побудови Єдиної судової інформаційно-телекомунікаційної системи, її структури та визначено етапи та терміни впровадження, кінцевий з яких датовано 2023 р. [17].

У межах реалізації проєкту здійснюється надсилання сторонам судового процесу повісток у формі sms-повідомлень, забезпечується участь особи в судовому засіданні в режимі відеоконференції, отримання копій процесуальних документів в електронній формі, проводиться автоматичний розподіл справ, фіксація судового процесу технічними засобами, реалізуються електронне судове діловодство та документообіг, електронний архів, судова статистика, узагальнення судової практики тощо.

Але 3 початком карантину, спричиненого пандемією коронавірусної інфекції COVID-19, перед українською судовою системою постали виклики як процесуального, так і організаційно-правового характеру. Не менш критичними стали проблеми технологій та технічних можливостей судів, матеріального та фінансового забезпечення. Нині в організації роботи судів основний акцент робиться на дотриманні балансу між забезпеченням права на доступ до правосуддя та убезпеченням учасників судового провадження, відвідувачів суду і працівників суду від поширення гострих респіраторних захворювань та COVID-19.

Пандемія прискорила процес судової діджиталізації. Протягом карантину суди у своїй роботі застосовували Zoom, Skype, Google Meet, але проблемами цих програм є незахищеність від зовнішнього втручання, часові обмеження, ідентифікація учасників тощо.

Досить слушним стало прийняття Верховною Радою України Закону України «Про внесення змін до деяких законодавчих актів, спрямованих на забезпечення додаткових соціальних та економічних гарантій у зв'язку з поширенням коронавірусної хвороби (COVID-2019)», відповідно до якого внесені зміни до процесуальних кодексів, у тому числі про те, що у судовому засіданні учасники справи можуть брати участь у режимі відеоконференції поза межами приміщення суду з використанням власних технічних засобів [18].

Разом із тим виникла необхідність удосконалення процедури ідентифікації особи, учасника справи, можливості повноцінної участі зазначеної особи як сторони судового провадження, подання сторонами заяв, клопотань та доказів у судовому засіданні в режимі відеоконференції без участі з боку учасників судового процесу (сторін) відповідального секретаря судового засідання.

08.04.2020 р. Державною судовою адміністрацією України було затверджено «Порядок роботи з технічними засобами відеоконференцзв'язку під час судового засідання в адміністративному, цивільному та господарському процесах за участі сторін поза межами приміщення суду» [20]. Нині проводиться робота над розробкою законопроєкту щодо організації дистанційного електронного правосуддя, що активно обговорюється в суддівській спільноті, ЗМІ, соцмережах. Вважаємо, що прийняття такого закону на часі та сприятиме успішній реалізації проєкту «Електронний суд».

Подальше впровадження електронного суду в Україні в час таких серйозних викликів передбачає системні дії щодо удосконалення законодавства, технічно-інформаційного забезпечення судів, розроблення заходів і систем забезпечення захисту інформації, правове регулювання питань відповідальності осіб за порушення в цій сфері, вжиття заходів попередження кіберзлочинності в цій сфері, проведення навчальних семінарів серед працівників апарату суду та інших користу- 
вачів системи, широку просвітницьку роботу серед населення, систематичний моніторинг ефективності роботи системи та їі постійну модернізацію.

Висновки. Таким чином, вважаємо, що електронний суд $\epsilon$ категорією адміністративного права, і з погляду науки та галузі адміністративного права це - складник електронного врядування, порівняно самостійна та унікальна форма судового адміністрування і юридичного процесу, заснованого на інформаційних технологіях, що забезпечують повний цикл руху документації та розгляду судової справи в електронному форматі, що має легальну юридичну природу. Проблеми впровадження електронного суду в Україні мають стати предметом дослідження адміністративно-правової науки, оскільки без належного наукового обґрунтування практичне його впровадження може бути малоефективним.

\section{Література}

1. Бринцев О.В. «Електронний суд» в Україні. Досвід та перспективи : монографія. Харків : Право, 2016. 72 с.

2. Куценко В.Д. Поняття та зміст адміністративно-правового забезпечення електронного суду. Науковий вісник публічного і приватного права. 2017. Вип. 6. Т. 2 С. 3-9.

3. Іваненко 0.Ю. Адміністративно-правовий аспект надання судових послуг в Україні : автореф. дис. ... канд. юрид. наук : 12.00.07. Запоріжжя. 2018. 18 c.

4. Крусян Р.А. Реформування судоустрою в Україні: досвід, сучасність, тенденції : дис. ... канд. юрид. наук : 12.00.10. Одеса, 2018. 255 с.

5. Берназюк О. Єдина судова інформаційнотелекомунікаційна система. Підприємництво, господарство і право. 2019. № 6. С. 326-329.

6. Погребняк О. Особливості запровадження електронного суду в цивільному процесі. Порівняльно-аналітичне право. 2018. № 1. С. 122-124.

7. Коршун А. Розвиток в Україні електронного правосуддя в контексті взаємодії суду та інститутів громадянського суспільства: теоретико-правова характеристика. Національний юридичний журнал: теорія і практика. 2017. С. 20-24.

8. Телешина Н. Реалізація електронного правосуддя в Росії (на прикладі арбітражного суду Владимирської області). Арбітражний і цивільний процес. 2014. № 6. С. 44-50.

9. Федосєєва Н., Чайковська М. Електронне правосуддя в Росії і світі. Адміністратор суду. 2011. № 3. C. 2.

10. Романенкова С. Поняття електронного правосуддя, його генеза і впровадження в правозасто- совчу практику зарубіжних країн. Арбітражний $i$ цивільний процес. 2013. № 4. С. 31.

11. Про судоустрій і статус суддів : Закон України від 02.06.2016 р. № 1402-VIII. (зі змінами). URL: https: / /zakon.rada.gov.ua/laws/show/1402-19\#n1495

12. Рекомендація CM/Rec (2009) $1 \mathrm{KM} P €$ державам-членам від 18 лютого 2009 р. URL: zakon.rada. gov.ua/go/994_937

13. Рекомендації Rec (2001) 3 KM PE. URL: sc.gov.ua/.../rekomendaciji

14. Про основні засади розвитку інформаційного суспільства в Україні на 2007-2015 роки : Закон України від 9 січня 2007 р. № 537-V. URL: https://zakon. rada.gov.ua/laws/show/537-16\#Text

15. Про проведення тестування підсистеми «Електронний суд» у місцевих та апеляційних судах : Наказ ДСА України від 22.12.2018 р. № 628. URL: https:// dsa.court.gov.ua/userfiles/media/628_18.pdf

16. Щодо неоднозначної практики застосування судами підсистеми «Електронний суд» : Рішення Ради суддів України від 20.09.2019 р. № 75. URL: https:// zib.com.ua/ua/print/139493pro_neodnoznachnosti_ zastosuvannya_sudami_sistemi_elektronni.html

17. Про забезпечення створення і функціонування Єдиної судової інформаційно-телекомунікаційної системи : Наказ ДСА України від 07.11.2019 року № 1056 URL: https://dsa.court.gov.ua/userfiles/ media/media/ECITC_Koncepcia.pdf

18. Про внесення змін до деяких законодавчих актів, спрямованих на забезпечення додаткових соціальних та економічних гарантій у зв'язку з поширенням коронавірусної хвороби (COVID-2019) : Закон України від 30.03.2020 р. № 540-IX. URL: https:// zakon.rada.gov.ua/laws/show/540-20\#Text

19. Порядок роботи з технічними засобами відеоконференцзв'язку під час судового засідання в адміністративному, цивільному та господарському процесах за участі сторін поза межами приміщення суду : Наказ ДСА України від 08.04.2020 р. № 169. URL: ttps://dsa.court.gov.ua/dsa/inshe/14/N_169_20

Обрусна С. Ю., доктор юридичних наук, доцент, професор кафедри державно-правових дисциплін Черкаського національного університету імені Богдана Хмельницького

Пасинчук К. М., кандидат педагогічних наук, доцент кафедри управління у сфері цивільного захисту Черкаського інституту пожежної безпеки імені Героїв Чорнобиля Національного університету цивільного захисту України 